Totally Unofficial 
This page intentionally left blank 


\title{
Totally Unofficial
}

\author{
The Autobiography of \\ R A P H A E L L E M K I N
}

Edited by Donna-Lee Frieze

\section{Yale \\ UNIVERSITY PRESS}

New Haven \& London 
Copyright $@ 2013$ by Donna-Lee Frieze.

All rights reserved. This book may not be reproduced, in whole or in part, including illustrations, in any form (beyond that copying permitted by Sections 107 and 108 of the U.S. Copyright Law and except by reviewers for the public press), without written permission from the publishers.

Yale University Press books may be purchased in quantity for educational, business, or promotional use. For information, please e-mail sales.press@yale.edu (U.S. office) or sales@yaleup.co.uk (U.K. office).

Designed by Sonia Shannon.

Set in Electra type by Keystone Typesetting, Inc.

Printed in the United States of America.

Library of Congress Cataloging-in-Publication Data

Lemkin, Raphael, 1900-1959.

Totally unofficial : the autobiography of Raphael Lemkin /

Raphael Lemkin, Donna-Lee Frieze.

pages $\mathrm{cm}$

Includes bibliographical references and index.

ISBN 978-0-300-18696-3 (hardback)

1. Lemkin, Raphael, 1900-1959. 2. Lawyers-Poland-Biography.

3. Lawyers-United States-Biography. 4. Human rights workers-

Poland-Biography. 5. Human rights workers-United States-Biography.

6. Genocide-Prevention. 7. Convention on the Prevention and

Punishment of the Crime of Genocide (1948) 8. World War, 1939-1945-

Atrocities. I. Frieze, Donna-Lee. II. Title.

KKP110.L46A3 2013

$345^{\prime} .0251092-\mathrm{dc} 23$

[B] 2012051175

A catalogue record for this book is available from the British Library.

This paper meets the requirements of ANSI/NISO Z39.48-1992 (Permanence of Paper).

10987654321 